\title{
Filozofia prawa Antoniego Peretiatkowicza
}

Dzieje polskiej nauki czasu I połowy XX w. obfitują w szereg doniosłych osiągnięć, swoim poziomem często nieodbiegających od ówczesnych światowych dokonań naukowych*. Gdy chodzi o nauki prawne, jednym z uczonych tego czasu był Antoni Peretiatkowicz (1884-1956), współtwórca i wykładowca Uniwersytetu w Poznaniu, ośrodka akademickiego, z którym związał większą część swojego życia. Antoni Peretiatkowicz zajmował się filozofią prawa, historią doktryn politycznych i prawnych, tudzież prawniczymi dyscyplinami dogmatycznymi, głównie prawem konstytucyjnym i administracyjnym. Wydaje się, że w dorobku naukowym polskiego badacza w pierwszej kolejności na uwagę zasługują jego przemyślenia z zakresu filozofii prawa, dyscypliny, do której powstania i upowszechnienia Peretiatkowicz swoimi pracami walnie się przyczynił. Wysoki poziom merytoryczny i oryginalność tych prac stanowią o umiejscowieniu ich w szeregu czołowych naukowych osiągnięć w Polsce pierwszej połowy XX w. Jako że rozważania polskiego autora w dużej mierze są ponadczasowe i tym samym zachowują aktualność, powinny one stanowić istotny punkt odniesienia we współczesnych dyskusjach o tematyce państwa i prawa.

Artykuł poświęcony jest przedstawieniu głównych zagadnień filozoficzno-prawnych poruszanych przez Peretiatkowicza oraz ukazaniu drogi kształtowania się jego poglądów naukowych. Na całokształt filozofii prawa autora składa się przede wszystkim jego stosunek do pozytywizmu prawniczego, uwagi metodologiczne dotyczące filozofii prawa jako odrębnej dziedziny nauki, autorska teoria prawa natury oraz studia nad twórczością Jana Jakuba Rousseau. W takim też porządku zostanie niżej zaprezentowana ta problematyka. Poprzedzona zostanie notą biograficzną, która przybliży życie Antoniego Peretiatkowicza.

\footnotetext{
*Artykuł stanowi poszerzoną wersję przygotowanej pod kierunkiem profesora Huberta Izdebskiego pracy magisterskiej.
} 
I. Antoni Peretiatkowicz urodził się 13 czerwca 1884 r. w Boruchowie na Wołyniu, w rodzinie ziemiańskiej pochodzenia rusińskiego ${ }^{1}$. Protoplastą rodu był Jacek Peretyatkowicz, osiadły na przełomie XVI i XVII stulecia w Rożyszczach. Z kolei w 1659 r. Krzysztofowi Peretyatkowiczowi został nadany herb za udział w walkach przeciwko Bohdanowi Chmielnickiemu. Wśród członków rodu doszukać się można wielu urzędników i wojskowych służących Rzeczypospolitej na przestrzeni wieków, jednakże w dziejach rodziny zarysowuje się raczej tradycja patriotyczno-cywilna, szczególnie intelektualna. Między przodkami Peretiatkowicza znaleźć można profesora Uniwersytetu Wileńskiego, innego znanego profesora greki i łaciny w Liceum Krzemienieckim, czy również, o czym warto wspomnieć w świetle tematu niniejszej pracy, znanego adwokata i sędziego ziemskiego łuckiego. Ciekawym szczegółem jest także znajomość prababki ze strony matki Peretiatkowicza z rodzicielką Słowackiego.

Mimo szlacheckich tradycji najbliższa rodzina Antoniego Peretiatkowicza nie była w stanie opłacić gruntownego wyższego wykształcenia przyszłego profesora. Znaczną finansową pomocą w tym względzie służył wuj Kazimierz Niemieksza. Dzięki jego zaangażowaniu Antoni Peretiatkowicz po ukończeniu w 1902 r. gimnazjum w Kamieńcu Podolskim może udać się na studia prawnicze do Warszawy. W 1905 r. zostają one jednakże przerwane, z powodu udziału młodego studenta $\mathrm{w}$ manifestacjach politycznych; zostaje on osadzony na kilka tygodni w więzieniu, po czym zwolniony, jednak z zakazem powrotu na carski uniwersytet. Studia kontynuuje przez kilka miesięcy w Berlinie, następnie przenosi się na Uniwersytet Lwowski, a ostatni rok studiów odbywa w Krakowie, gdzie na Uniwersytecie Jagiellońskim w 1909 r. uzyskuje stopień doktora nauk prawnych. Będąc w Krakowie, odbył w latach 1907-1910 również studia filozoficzne. Już w czasach studenckich zajmuje się głębiej problematyką naukową, publikuje w kilku ważnych czasopismach naukowych, a za rozprawę poświęconą komparatystyce prawniczej zdobywa w konkursie „Gazety Sądowej Warszawskiej” nagrodę w wysokości 100 rubli, co stanowiło na owe czasy kwotę nie do pogardzenia.

${ }^{1}$ Informacje zawarte w niniejszej części zostały głównie oparte na następujących opracowaniach: Akademia żałobna dla uczczenia pamięci prof. dra Antoniego Peretiatkowicza, „Ruch Prawniczy i Ekonomiczny" 1958, z. 1, s. 325-334; A. Gulczyński, Antoni Peretiatkowicz, [w:] Poczet rektorów Almae Matris Posnaniensis, (red.) T. Schramm, Poznań 2004, s. 113-124; idem, Antoni Peretiatkowicz. Redaktor naczelny 1921-1939, „Ruch Prawniczy, Ekonomiczny i Socjologiczny” 2006, z. 2, s. 69-72; R. Klimowiecki, Antoni Peretiatkowicz, „Państwo i Prawo” 1957, z. 2, s. $343-$ -345; K. Pol, Poczet prawników polskich, Wydawnictwo C.H. Beck 2000, s. 1127-1141; A. Peretiatkowicz, Wołyński ród Peretiatkowiczów, „Wołyń bliżej” 2000, nr 4, s. 66-83; 2001, nr 1, s. 54-68; A. Płoszewski, Prof. dr Antoni Peretiatkowicz, „Wyboje” 1957, nr 3; A. Redzik, Antoni Peretiatkowicz jako profesor Uniwersytetu Lwowskiego (1918-1919), „Czasopismo Prawno-Historyczne” 2007, z. 1, s. 205-207; Z.T. Wierzbicki, Antoni Peretiatkowicz (1884-1956), „Kultura i Społeczeństwo" 1997 , nr 1, s. 159-167. 
Po obronie doktoratu Antoni Peretiatkowicz postanawia kontynuować edukację za granicą. Wyjeżdża wpierw na studia do Paryża, następnie kieruje się do Genewy, gdzie spędza ponad dwa lata na badaniach w znanych Archives J. J. Rousseau. Przenosi się potem do Heidelbergu, gdzie bierze udział w seminariach Georga Jellinka i Gustawa Radbrucha, zawiązując z tymi myślicielami serdeczną znajomość. Okres zagranicznych podróży Peretiatkowicza jest niezmiernie ważny w rozwoju jego pracy naukowej, ponieważ wyznacza główne osie jego horyzontu badawczego. Jak będzie to wykazane dogłębniej w dalszej części niniejszej pracy, we Francji styka się z rosnącą falą zainteresowania problematyką filozofii prawa, pobyt w Genewie zaowocuje jego opus magnum, mianowicie rozprawą poświęconą koncepcji Jana Jakuba Rousseau, natomiast w Niemczech znajdzie się pod wpływem filozofii neokantowskiej, silnie kształtującej jego własne stanowisko naukowe.

Omawiany okres życia Peretiatkowicza nie był jednakże tylko czasem nauki. Młody badacz już podczas studiów w Warszawie, co wzmiankowano, bierze czynny udział w działaniach niepodległościowych. Również za granicą wołyński szlachcic nie uchyla się od patriotycznego zaangażowania. Wstępuje bowiem do Związku Młodzieży Polskiej (tzw. „Zet”), organizacji skupiającej studiujących poza granicami kraju Polaków. Zostaje w niej członkiem Koła Braterskiego, najwyższym szczeblu w trójstopniowej strukturze Związku. Nie dziwią zatem jego endeckie sympatie. Z Narodową Demokracją będzie Peretiatkowicz związany jeszcze przez kilka lat już w niepodległej Polsce, będzie publikował artykuły publicystyczne na łamach „Kuriera Warszawskiego” i „Przeglądu Wszechpolskiego”. Utrzymuje kontakty z Romanem Dmowskim, zwłaszcza że w Poznaniu mieszkają w sąsiedztwie. Gwoli ścisłości, z biegiem lat Peretiatkowicz zmieni sympatie polityczne i w $1926 \mathrm{r}$. przejdzie do grona zwolenników „obozu sanacyjnego”.

Powracając do naruszonego porządku chronologicznego wywodu, trzeba wskazać, że po zagranicznych studiach młody doktor powraca w 1914 r. do Krakowa. Na podstawie wydanej rok wcześniej monografii Filozofia prawa Jana Jakóba Rousseau'a Peretiatkowicz habilituje się na Uniwersytecie Jagiellońskim, na której to uczelni będzie wykładał jako docent prywatny filozofię prawa. Przetłumaczył na język polski Umowę społeczna szwajcarskiego myśliciela, którą wydał w 1918 r. W tym roku przyjmuje ofertę obsadzenia katedry filozofii prawa na Uniwersytecie Lwowskim, na którym jednak zajęć nie uda mu się poprowadzić - wpierw z uwagi na urlop udzielony z powodu wyjazdu naukowego do Grazu, a następnie z racji zawieszenia zajęć na uczelni spowodowanego mobilizacją $\mathrm{w}$ związku z walkami polsko-ukraińskimi o Lwów. Przyjmuje posadę na powstającym Katolickim Uniwersytecie Lubelskim, lecz tylko na okres trzech miesięcy, po czym przenosi się już na stałe do Poznania, gdzie zaproponowano mu stanowisko profesora na zakładanym tam wówczas uniwersytecie. 
Od pierwszych chwil żywo angażuje się w powstające struktury akademickie. Daje poznać się jako zręczny i fachowy organizator, potrafiący zjednać sobie ludzi otwartością, wysoką kulturą osobistą i ogładą towarzyską. Dokłada wszelkich starań, aby poznańska uczelnia jak najszybciej zaczęła normalnie pracować. Koncentruje się na sprawach Wydziału Prawa (później PrawnoEkonomicznego), w jego powstaniu odgrywa rolę pierwszoplanową i zostaje jego pierwszym dziekanem. Obejmuje z początku również katedrę encyklopedii i filozofii prawa, a następnie katedrę nauki o państwie i prawie politycznym.

Przykłada dużą wagę do związku prawa i ekonomii. Uważa, że te dwie dziedziny pozostają ze sobą w ścisłej relacji i w ramach studiów powinny być wykładane obok siebie. Dowodem na to jest wydzielenie na nowym wydziale dwóch pionów nauczania: prawniczego oraz ekonomicznego. Pogłębieniu współpracy prawników i ekonomistów służyć ma też założenie w 1920 r. w Poznaniu Towarzystwa Prawniczego i Ekonomicznego. Przekonanie o bliskości prawa i ekonomii przejawia się również w profilu założonego przez Peretiatkowicza czasopisma naukowego, mianowicie „Ruchu Prawniczego i Ekonomicznego". Akcentowanie potrzeby kształcenia wszechstronnego i interdyscyplinarnego wpłynie z czasem na rozszerzenie problematyki poruszanej na łamach pisma o zagadnienia socjologiczne. Nieprzypadkowo od 1925 r. periodyk nosić będzie tytuł „Ruch Prawniczy, Ekonomiczny i Socjologiczny”. Od momentu jego założenia aż do roku 1939 Peretiatkowicz był jego redaktorem naczelnym, przykładającym wszelkich starań do wysokiej jakości merytorycznej artykułów i profesjonalnej redakcji, co w początkowych okresach dużych trudności finansowych jest tym bardziej warte uznania. Czasopismo szybko zdobyło stałe miejsce wśród głównych tego typu pism w kraju. Na jego łamach publikowali wybitni uczeni krajowi (np. W. L. Jaworski, K. Kumaniecki, J. Makarewicz, F. Znaniecki, E. Lipiński), jak również zagraniczni (R. Poincaré, H. Kelsen, J. Barthélemy). Antoni Peretiatkowicz zdawał sobie doskonale sprawę z wagi kontaktów międzynarodowych w świecie nauki. Zabiegał o wymianę poglądów i doświadczeń z czołowymi europejskimi uczonymi, organizował konferencje, seminaria i odczyty, na których wymiana ta ma szansę się rozwijać. Zostaje prezesem Towarzystwa Przyjaźni Polsko-Francuskiej, a za pracę na tym stanowisku zostaje odznaczony przez rząd francuski w 1936 r. Komandorią Orderu Legii Honorowej.

Jednocześnie ciągle angażuje się w rozbudowę struktur akademickich w Poznaniu. Nie poprzestaje na organizowaniu uniwersytetu i fakultetu prawa, lecz czynnie udziela się przy powstaniu Wyższej Szkoły Handlowej. Dzięki jego staraniom uzyska ona w 1938 r. status szkoły akademickiej i przemianowana zostanie na Akademię Handlową. W tym samym roku prof. Peretiatkowicz zostanie jej rektorem, sprawując jednocześnie od 1936 r. również funkcję rektora na Uniwersytecie Poznańskim. Aby dopełnić obraz działalności organizacyjnej polskiego naukowca, trzeba wspomnieć jeszcze o inicjaty- 
wie utworzenia w 1934 r. Instytutu Prawa Publicznego i Nauk Politycznych, poświęconego badaniom prawa publicznego, administracyjnego, jak również zajmującego się analizą współczesnych nurtów politycznych. Podobnego rodzaju instytucją, w której Peretiatkowicz czynnie działał, było stowarzyszenie Polski Instytut Prawa Publicznego, zrzeszające uczonych z całego kraju.

Przedstawione zostały wyżej głównie dokonania poznańskiego profesora na polu organizacyjnym, ważne i godne najwyższego uznania, lecz nie stanowiące w pierwszej kolejności o formacie intelektualnym tego uczonego. Antoni Peretiatkowicz to przede wszystkim intelektualista i naukowiec, poruszający się z ogromną sprawnością po licznych dziedzinach wiedzy. Zajmuje się filozofią prawa, historią idei, jak również nie stroni od głębszego namysłu nad dogmatycznymi rodzajami prawa, zwłaszcza państwowego (dzisiaj konstytucyjnego) i administracyjnego. Jego szerokie horyzonty myślowe znajdują wyraz $\mathrm{w}$ imponującym dorobku piśmienniczym obejmującym szereg artykułów, monografii, studiów oraz podręczników. Jak wspomniano, już w czasach studenckich publikuje, zajmując się głównie problematyką filozoficzno-prawną. Szybko przechodzi do wnikliwych analiz nad twórczością Jana Jakuba Rousseau, których wynikiem jest największe dzieło Peretiatkowicza - monografia poświęcona temu myślicielowi. Na przestrzeni lat dogłębnym badaniom podda również teorie Hansa Kelsena, Georga Jellinka, Georgesa Sorela, Niccolo Machiavellego, Andrzeja Frycza-Modrzewskiego.

Z kolei na jego podręcznikach wychowają się liczne zastępy studentów. Pisze m.in. Zarys encyklopedii prawa (Poznań 1923), redaguje Wstęp do nauk prawnych. Encyklopedia prawa obowiazujacego w Polsce (wydawana w latach 1923-26, dziewięciokrotnie wznawiana), wielkim powodzeniem cieszy się podręcznik Państwo współczesne, który doczekał się dziesięciu wydań. Dużą popularność zdobywa opracowana wspólnie z Janem Bystroniem i Stanisławem Pawłowskim książka Polska współczesna (pięć wydań). Uzupełni znany podręcznik historii doktryn politycznych i filozofii prawa autorstwa Paula Janeta o część dotyczącą myśli XIX i XX w. Do szerszego grona czytelników kieruje natomiast prace popularyzatorskie, np. Współczesna encyklopedie polityczna (Poznań 1926, później rozszerzoną) i Wspótczesna kulture polska (Poznań 1932). Jest ponadto autorem artykułów publicystycznych poruszających bieżące sprawy życia publicznego.

Wszystkie dzieła Peretiatkowicza cechuje przystępny i klarowny język oraz przejrzysta i elegancka w swojej prostocie linia wywodu. Najtrudniejsze kwestie naukowe, kontrowersje czy spory w doktrynie potrafi przedstawić w sposób zwięzły i zrozumiały, nie tracąc przy tym zasadniczej rzetelności naukowej. Umiejętność logicznej oraz klarownej argumentacji cechuje Profesora, zjednując mu rzesze słuchaczy na wykładach i seminariach, jak również zaskarbiając dużą liczbę czytelników opracowań. Reasumując, Peretiatkowicz to nie tylko świetny, wnikliwy naukowiec, ale także doskonały dy- 
daktyk. Ponadto jego erudycja, szerokie horyzonty badawcze i wszechstronne zainteresowania pozwalają zaliczyć go do grona światłych intelektualistów, niezamykających się w jednej, specjalistycznej dziedzinie, ale ujmujących naukę z szerokiej perspektywy, dostrzegających różnorodne związki pomiędzy niejednokrotnie odległymi od siebie polami wiedzy.

Aby ukazać jeszcze dokładniej wszechstronność umysłu poznańskiego uczonego, należy wskazać, że zajmuje się on również pracą tłumaczeniową. Oprócz wspomnianego przekładu Umowy społecznej, do dziś wznawianego, tłumaczy również Państwo Słońca Tomaso Campanelli, Ogólną naukę o państwie Georga Jellinka oraz dzieło Herberta Spencera $O$ wychowaniu umystowym, moralnym i fizycznym. $Z$ jego inicjatywy przywołany wyżej podręcznik Paula Janeta został przełożony na język polski.

Główna część działalności naukowej Antoniego Peretiatkowicza przypada na dwudziestolecie międzywojenne. Przed pierwszą wojną światową pochodzący w Wołynia młody adept zdobywa gruntowne wykształcenie prawnicze i filozoficzne na renomowanych uczelniach polskich i zagranicznych oraz broni rozprawę doktorską. Lata 20. i 30. wypełniają mu wielorakie obowiązki naukowe, dydaktyczne i organizacyjne, dzięki którym zdobywa bezapelacyjnie czołową pozycję w świecie polskiej nauki, zaznaczając się również poza granicami kraju. Przed wybuchem drugiej wojny światowej dochodzi do najwyższych stanowisk. Zostaje, jak była o tym mowa, rektorem Uniwersytetu Poznańskiego i Akademii Handlowej, wciąż piastuje funkcję redaktora naczelnego „Ruchu”. Ponadto zostaje w 1937 r. powołany w skład Trybunału Kompetencyjnego w Warszawie, a dwa lata później obejmuje stanowisko sędziego Najwyższego Trybunału Administracyjnego.

Po wybuchu wojny niemieccy okupanci wysiedlają prof. Peretiatkowicza i jego rodzinę z Poznania na teren Generalnego Gubernatorstwa. Do powstania warszawskiego w 1944 r. przebywa w Warszawie, wykładając w Miejskiej Szkole Handlowej Edwarda Lipińskiego. Po upadku powstania trafia do obozu w Pruszkowie, a następnie prowadzi wykłady z prawa administracyjnego na tajnych kompletach w Piotrkowie Trybunalskim. Po wyzwoleniu Poznania wraca w marcu 1945 r. do wielkopolskiej stolicy, z którą związał przeważającą część swojego życia.

Lata powojenne nie są łatwym okresem w historii Polski, trudno jest się większości jej mieszkańców przystosować do nowych, całkowicie innych, realiów. Szczególnie zmiana ta dotyka przedstawicieli przedwojennej inteligencji. Nowe władze zmuszają ich do dokonywania trudnych wyborów, w świecie „bezpieki” i cenzury często stawać muszą w obliczu beznadziejnych dylematów. Przystosowanie się do nowej rzeczywistości, znalezienie w niej swojego miejsca pociąga częstokroć za sobą trudne do oceny zachowania. Problem ten dotyka prof. Peretiatkowicza w całej swej rozciągłości i z tego względu wymaga krótkiej wzmianki. 
Profesor po zakończeniu wojny przystępuje z powrotem do prowadzenia wykładów na obydwu wcześniejszych uczelniach, przy czym w $1951 \mathrm{r}$. musi odejść z Akademii Handlowej. Jednakże jego wykłady stają się na wzór sowiecki czytane, przedstawiana $\mathrm{w}$ nich treść ogranicza się do referowania innych myślicieli, bez własnego komentarza. W pracy badawczej zajmuje się tematyką „,bezpieczniejszą”, bardziej neutralną z punktu widzenia władz państwowych. To właśnie w tym okresie tłumaczy pisma Campanelli czy Spencera, analizuje doktrynę Andrzeja Frycza-Modrzewskiego. Wydaje wprawdzie jeszcze w 1949 r. monografię o Rousseau, z niewielkimi modyfikacjami. Zasadnicza linia wywodu i konkluzje tej pracy nie ulegają zmianie, zastąpiony zostaje w niej jedynie rozdział poświęcony filozofii karnej, w którym poruszana była m.in. problematyka kary śmierci, rozdziałem dotyczącym idei demokracji społecznej. Z kolei w życiu pozauczelnianym Peretiatkowicz wstępuje do Stronnictwa Demokratycznego, zostaje członkiem Komitetu Redakcyjnego „Państwa i Prawa”, powołany jest jako biegły w procesie Arthura Greisera, angażuje się w odbudowę Izby Przemysłowo-Handlowej. Jego stosunek do socjalizmu jest zniuansowany, ponieważ jak zauważa Zbigniew T. Wierzbicki, Peretiatkowicz „będąc przeciwnikiem komunizmu i potępiając jego bezecne barbarzyństwa, uważał, iż ustrój PRL-u jest społecznie znacznie sprawiedliwszy niż przedwojenny kapitalizm"2.

Najcięższe czasy przychodzą wraz z nastaniem 1950 r., kiedy mrzonki o jakimkolwiek „liberalizmie” rozwiewają się ostatecznie. W marcu tegoż roku zostaje usunięty z komitetu „Państwa i Prawa”. W latach 1953-55 Peretiatkowicz musi prowadzić wykład o ustroju ZSRR, dnia 1 października 1955 r. wygłasza przemówienie inauguracyjne „Zasady praworządności socjalistycznej”, a rok później wydaje zgodny z ogólnymi „wytycznymi” artykuł o systemie Stanów Zjednoczonych. Warunki owego czasu nie sprzyjają rozwojowi wolnej myśli. Już w 1957 r. stwierdzono, że „w okresie lat 1950-55 działalność naukowa prof. Peretiatkowicza została zahamowana. Jego indywidualizm twórczy nie mógł pogodzić się z dyrygowanym odgórnie stylem pracy naukowej, apriorycznym stawianiem tez"3.

Nie jest łatwo ocenić PRL-owski okres w życiu Antoniego Peretiatkowicza. $\mathrm{Z}$ jednej bowiem strony wypada stawiać wielkim uczonym wysokie wymagania, z drugiej nie można uciekać od pytania, czy brak heroizmu w niezwykle trudnych czasach terroru może być powodem do hańby. Z perspektywy ideałów postawa Peretiatkowicza do najzaszczytniejszych nie należy. Zrozumiały staje się zarzut oportunizmu za wyrzeczenie się wcześniejszego stanowiska w kwestii prawa natury. Jak pisze Maria Szyszkowska, Peretiatkowicz „po roku 1950-tym zajął postawę oportunistyczną i uznał, że poprzednio zajmo-

\footnotetext{
${ }^{2}$ Z.T. Wierzbicki, op. cit., s. 160-161.

${ }^{3}$ A. Płoszewski, op. cit.
} 
wał błędne stanowisko. Powołując się na marksizm, ocenił teorie prawa natury za nienaukowe"4. Nie można jednak zapominać o nadzwyczajnym kontekście historycznym i towarzyszącej każdemu typowo ludzkiej potrzebie znalezienia własnego miejsca w świecie. Piszący te słowa, choćby z racji swego wieku, nie poczuwa się do rozstrzygnięcia omawianej kwestii. Może wskazać jedynie, że przedstawiony wyżej trudny czas w życiu Profesora powinien być przedmiotem głębszej uwagi i namysłu, ale nie celem osądzenia, lecz zrozumienia. Poza tym, być może w warunkach „odwilży” po 1956 r. powróciłby Antoni Peretiatkowicz w większym stopniu do swojego dawnego stylu pracy. Niestety, nie była dana mu ta szansa; w wyniku nieudanej operacji umiera 18 grudnia 1956 r.

II. 1. Przystępując do przedstawienia głównych elementów filozofii prawa Antoniego Peretiatkowicza, należy wpierw zauważyć, że właściwe i dogłębne zrozumienie każdego w zasadzie systemu myślowego wymaga choćby tylko pobieżnego ustalenia warunków historycznych, wśród których dana myśl powstawała. Po pierwsze, pozwoli to dostrzec często ukryte i niewypowiedziane, gdyż dla danego twórcy oczywiste, założenia, na których dana teoria została ufundowana. Po drugie, odczytanie pewnych przemyśleń wprost, bez odpowiedniego zaznajomienia się z tłem historycznym im towarzyszącym, grozić może całkowitym zrelatywizowaniem myśli oryginalnej do panujących współcześnie trendów i poglądów, co byłoby w najgorszym wypadku jedynie afirmacją obecnego stanu nauki. Po trzecie wreszcie, znajomość epoki, w której dana myśl powstała, pozwoli w sposób niezaprzeczalny ustalić jej miejsce w świecie idei, co stanowi niewątpliwie istotny walor dydaktyczny. Z tych względów studia nad filozofią prawa Antoniego Peretiatkowicza wypada rozpocząc od wskazania głównych nurtów naukowych czasów, w których uczony ten żył, zwłaszcza że nurty te pozostają w ścisłym związku z formowaniem naukowego stanowiska polskiego uczonego.

Na kształcie myśli filozoficzno-prawnej Antoniego Peretiatkowicza zaważyły przede wszystkim cztery zjawiska, czy może ściślej grupy zjawisk, będące istotnymi determinantami świata prawniczego przełomu XIX i XX w.:

1) odejście od dominujących w XIX w. założeń szkoły historycznej i pozytywizmu prawnego;

2) ukonstytuowanie filozofii prawa, jako nowej i odrębnej dyscypliny nauk prawnych;

3) rozwój filozofii neokantowskiej i teorii prawa natury o zmiennej treści;

4) wzrost zainteresowania badaniami poświęconymi Janowi Jakubowi Rousseau.

Procesy powyższe pozostawały ze sobą w ścisłym związku oraz były wyrazem panującego na przełomie stuleci klimatu intelektualnego. Antoni Pe-

\footnotetext{
${ }^{4}$ M. Szyszkowska, Zarys filozofii prawa, Białystok 2000, s. 224.
} 
retiatkowicz uważnie śledził ich przebieg, żywo zainteresowany toczącymi się wokół nich dyskusjami naukowymi, a zabierając głos, formułuje własne stanowisko filozoficzno-prawne. $Z$ tego powodu rekonstrukcja filozofii prawa Antoniego Peretiatkowicza uwzględniać musi analizę jego stosunku do wyżej wymienionych zjawisk.

2. Jak wiadomo, szkoła historyczna i pozytywizm kształtowały przez większą część XIX stulecia sposób myślenia prawniczego oraz postrzegania prawa. Generalnie był to czas odejścia od popularnych w Oświeceniu nurtów prawnonaturalnych. Prawnik miał niejako w sposób automatyczny stosować prawo postrzegane jako zwarty system. W przypadku luk w prawie, czy spraw szczególnie skomplikowanych lub problematycznych, poszukiwanie historycznej woli prawodawcy, jak twierdzili przedstawiciele historyzmu, miało skutecznie rozwiązać tego typu trudności. Pozytywiści natomiast uważali, że traktowanie prawa jako kompletnego zbioru norm i odczytanie go przy użyciu metod formalnych pozwoli na wydanie sprawiedliwego orzeczenia w każdej sprawie. Elementem łączącym te dwa podejścia była niewątpliwa niechęć do odwoływania się w rozważaniach nad prawem do jakichkolwiek abstrakcyjnych wzorców, wykraczających poza rzeczywistość dostępną empirycznie. Zwolennik historyzmu sięgał do zapisów przeszłości, często poszukiwał prawa zwyczajowego, pozytywista $\mathrm{z}$ kolei ograniczał się do wyrażonej w ustawach woli prawodawcy.

Kilkadziesiąt lat operowania podanymi metodami przynosi jednak szereg rozczarowań, związanych w pierwszej kolejności z częstym w praktyce zjawiskiem luk prawnych, czyli miejsc, w których ustawodawca swej woli nie wyraził. Pojawiają się nowe koncepcje, starające się problemowi zaradzić, rozszerzając tradycyjne sędziowskie instrumentarium. Wskazać wypada choćby na szkołę „liberalizmu prawnego" (modernizmu prawnego), zwłaszcza że jest ona przedmiotem analiz Peretiatkowicza. Nurt ten znajduje wyraźny odzew i szerzy się w krajach Europy Zachodniej ${ }^{5}$. Reprezentanci tego kierunku postulują powierzenie sędziemu pewnej swobody orzeczniczej w przypadku napotkania luki w prawie, aby zniwelować rozdźwięk między ,jurysprudencją a życiem praktycznem, pomiędzy sędzią a społeczeństwem”; podkreśla się, że prawo nie powinno być oderwane od wymogów społeczno-gospodarczych ${ }^{6}$.

Przyczyn wystąpienia nowego prądu w jurysprudencji Peretiatkowicz upatruje, z jednej strony, w ogólnych przemianach filozoficznych owego czasu, a konkretniej w zaistnieniu na terenie filozofii ogólnej woluntaryzmu, wysuwającego na plan pierwszy nie intelekt czy uczucie, ale wolę, a z drugiej strony w zjawi-

\footnotetext{
${ }^{5}$ A. Peretiatkowicz, Zagadnienie stosunku sędziego do ustawy na terenie niemieckim, „Gazeta Sądowa Warszawska" 1912, nr 19-21, s. 284-285.

${ }^{6}$ Ibidem, s. 285 . We wszystkich przywołanych cytatach zachowana została pisownia oryginalna.
} 
skach praktycznych, wskazujących, że ustawy nienadążające za coraz szybciej zmieniającą się rzeczywistością nie są w stanie zapewnić jednolitego wymiaru sprawiedliwości ${ }^{7}$. Dostrzegając potrzebę modyfikacji tradycyjnych, dotychczasowych doktryn prawnych, polski badacz nie przyjmuje bezkrytycznie postulatów modernistów, lecz rozpatruje ich program z punktu widzenia istoty prawa, sprowadzającej się, jego zdaniem, do sankcji społeczno-państwowej, celowości społecznej oraz stałości i określoności przepisów ${ }^{8}$. W tym świetle zauważa, że modernizm prawny, obdarzając sędziego rozległą swobodą orzeczniczą, zbytnio narusza obiektywizm prawa, a tym samym bezpieczeństwo prawne, co nie jest, w oczywisty sposób, zgodne z istotą prawa, które ma być stałe9 .

Aby wybrnąć z problemu wyboru między sztywną, oderwaną często od potrzeb społecznych metodą tradycyjną, a niepozbawionym wad ,liberalizmem", Peretiatkowicz proponuje dwie modyfikacje nowego prądu. Po pierwsze, wskazuje na konieczność zwracania uwagi, w przypadku napotkania luki prawnej, na całokształt przepisów prawnych, na ratio iuris zwłaszcza nowszych ustaw, aby zbadać na tej podstawie obecną wolę ustawodawcy ${ }^{10}$. Przeciwstawia się tym samym zasadom szkoły historycznej, koncentrujących

${ }^{7}$ Idem, Prąd nowy w prawoznawstwie, Lwów 1912, s. 12-16.

${ }^{8}$ Ibidem, s. 27. Mimo jasno tutaj wyrażonego poglądu na temat istoty prawa, nie można uznać, że stanowisko Peretiatkowicza w tej kwestii jest do końca konsekwentne. Wskazują na to rozważania poświęcone zjawisku wojny (por. idem, Wojna a idea prawa [w:] idem, Studia prawnicze, Poznań 1938, s. 153-179). Uczony bowiem chcąc zbadać, czy fakt wojny da się pogodzić z istotą (ideą) prawa, w konkluzji relatywizuje problem do obranego światopoglądu. W świetle światopoglądu nazwanego indywidualistycznym, który stawia dobro jednostki na pierwszym miejscu i rozpatruje wszelkie instytucje prawno-społeczne z punktu widzenia ich użyteczności dla człowieka, wojna nie może zostać zaakceptowana. Przeciwnie, na gruncie światopoglądu nadindywidualistycznego, gdzie uznaje się, że pewne instytucje, takie jak np. państwo, prawo, Kościół są celami samymi w sobie, którym jednostka ma się podporządkować. W tej perspektywie wojna jest czymś dopuszczalnym, a często nawet zalecanym, bo kształtującym duszę obywatela. Jak więc widać, Peretiatkowicz nie ustala przy tej okazji apriorycznej idei prawa, lecz eksportuje problem w obszar pozajurydyczny. Osobiście wyraża jedynie zapatrywanie o potrzebie poszukiwania syntezy dwóch powyższych stanowisk w kwestii wojny (ibidem, s. 178-179), chociaż z drugiej strony, jak zauważa Anna Kryniecka-Piotrak, „dokonany przez Peretiatkowicza wybór podstawowej wartości, mającej leżeć u podstaw prawa pozytywnego oraz proponowanych rozwiązań społecznych, zdecydowanie zbliża jego poglądy do indywidualistycznego kierunku filozofii” (A. Kryniecka-Piotrak, Światopogląd w filozofii prawa wedlug Antoniego Peretiatkowicza, [w:] M. Szyszkowska, Filozofia prawa i jej wspótczesne znaczenie, Warszawa 2002, s. 126).

${ }^{9}$ A. Peretiatkowicz, Prąd nowy..., s. 28-31. Nietrudno zauważyć, że stanowisko Peretiatkowicza, gdy chodzi o odwołanie do istoty prawa, przypomina poglądy Gustawa Radbrucha. Jedyna różnica między tymi autorami polega na tym, że Radbruch uznał za element idei prawa obok celowości i bezpieczeństwa prawnego sprawiedliwość, a nie jak Peretiatkowicz sankcję społecznopaństwową. Natomiast niewątpliwym podobieństwem między obydwoma badaczami jest akcentowanie roli bezpieczeństwa prawnego. Odnośnie do Radbrucha, mowa w tym miejscu oczywiście przede wszystkim o jego wcześniejszej fazie twórczości (do 1933 r.). Szerzej na temat. myśli Radbrucha por. J. Zajadło, Formuła Radbrucha. Filozofia prawa na granicy pozytywizmu prawniczego i prawa natury, Gdańsk 2001.

${ }^{10}$ A. Peretiatkowicz, Prąd nowy..., s. 42-43. 
się na historycznych badaniach rozwoju prawa, a jednocześnie ogranicza postulowaną przez modernistów swobodę sędziowską. Temu samemu celowi ma służyć druga zasada, nakazująca sędziemu, w razie braku konkretnego unormowania, odwołać się do zespołu społecznych przekonań, zwyczajów, poglądów i stosowanych praktyk do czegoś, co Peretiatkowicz nazywa ogólnie mianem poczucia prawnego społecznego, aby zapadłe rozstrzygnięcie pozostawało w możliwie jak największej bliskości z życiem społecznym i dyktowanymi przez nie wymogami.

Finalną konkluzję polski uczony formułuje w postaci następującej dyrektywy: „W wypadkach przez ustawę nieprzewidzianych winien sędzia swobodnie określić normę ze względu na potrzeby społeczne najwłaściwszą uwzględniając stanowisko współczesnego ustawodawcy (moderna ratio iuris) oraz poczucie prawne społeczne", przy czym należy badać poczucie społeczne grupy, w której dany spór miał miejsce, co oznacza, że np. w sprawach przemysłowych niewłaściwym byłoby odwołanie się do poczucia społecznego rolników ${ }^{11}$. Pogląd ten z pewnością jest udanym kompromisem między odmiennymi kierunkami, opiera się na ich krytycznym rozpatrzeniu i wyborze spośród nich najcenniejszych zasad. Gwoli ścisłości warto jeszcze wskazać, że ani Peretiatkowicz, ani przedstawiciele omawianego nowego prądu modernistycznego nie negują pierwszoplanowej roli prawa pozytywnego, lecz jedynie koncentrują się na zaradzeniu sytuacji, w której ustawa nie dyktuje żadnego unormowania (luka w prawie). Stanowisko polskiego naukowca w swoim fundamencie jest pozytywistyczne, ale nie w skrajnym i ortodoksyjnym sensie, lecz w złagodzonej oraz otwartej na większy aktywizm orzeczniczy postaci. Jednocześnie wpisuje się ono w szerszy nurt zmiany dotychczas funkcjonującego paradygmatu prawniczego, nurtu niezamkniętego tylko w akademickich gabinetach, ale obecnego również w praktyce. Jak sam Peretiatkowicz konstatuje, mimo licznych głosów krytycznych ze strony prawników-praktyków, daje się zauważyć, że postulaty „liberalizmu prawnego" $\mathrm{w}$ dużej mierze przenikają jednak do świadomości prawnej ${ }^{12}$.

3. Potrzeba wyjścia poza ustawę i tym samym poszukiwanie sprawiedliwego rozstrzygnięcia sądowego $\mathrm{w}$ przestrzeni nieobjętej tradycyjnym ustawodawstwem prowokują, w naturalny sposób, do głębszego namysłu nad, wyrugowaną przez pozytywistów, stroną filozoficzną prawa. Peretiatkowicz zauważa duże poruszenie w kierunku badań filozoficzno-prawnych w Niemczech $^{13}$. Podobnie sytuacja wygląda we Francji, gdzie potrzeby praktyki

${ }^{11}$ Ibidem, s. 48.

${ }^{12}$ Idem, Zagadnienie..., s. 318-319.

${ }^{13}$ Idem, Literatura encyklopedyi i filozofii prawa w latach ostatnich, Kraków 1916, s. 8. Książka ta zawiera systematyczny i interesujący przegląd ówczesnych, polskich i zagranicznych, prac naukowych poświęconych teoretycznym i filozoficznym badaniom nad prawem. 
i interpretacji rodzą wzrost znaczenia tego rodzaju rozważań ${ }^{14}$. Okazało się bowiem, że stosowana powszechnie metoda historyczna zawodzi, gdyż uzyskana za jej pomocą przypuszczalna wola ustawodawcy może nie odpowiadać współczesnym wymaganiom i w związku z tym potrzeba sięgnięcia poza ustawę do pewnych niezmiennych zasad rozumowych staje się koniecznością ${ }^{15}$. Kieruje to uwagę prawników w stronę teorii prawa natury, która, mimo wyparcia i nikłej popularności w XIX w., z powrotem zaczyna wzbudzać zainteresowanie.

Jakkolwiek mówienie o prawie naturalnym w drugiej połowie XIX stulecia staje się coraz częściej spotykane, to Peretiatkowicz, doceniając i aprobując ten prąd myślowy, woli mówić nie o odrodzeniu prawa natury, lecz raczej o powstaniu nowej dyscypliny akademickiej, mianowicie filozofii pra$\mathrm{wa}^{16}$. Jego zdaniem posługiwanie się sformułowaniem ,prawo natury” nie jest w ogóle zbyt fortunne, ponieważ na przełomie XIX i XX stulecia nadaje się mu inne znaczenie niż w wiekach ubiegłych. Nie oznacza ono bowiem pozostającego do odkrycia zespołu obiektywnych norm, ale jest wyrazem wyrażanych pod adresem obowiązującego prawa postulatów i pożądanego kierunku jego zmian. Zmodyfikowane teorie prawa natury opierają się na pewnego rodzaju nastawieniu krytycznym, przejawiającym się w poglądach poszczególnych osób. Badacz zwraca uwagę, że „staje się więc prawo naturalne aktem wiary, przejawem uczucia"17. Ponadto, uzasadniając jeszcze odrzucenie zwrotu ,prawo natury”, stwierdza, iż „w oczach nauki wszystko jest naturalne, bo wszystko jest niezbędnym skutkiem pewnych przyczyn" oraz natura (przyroda) nie zna praw, tylko fakty ${ }^{18}$. Zdaniem Peretiatkowicza, lepiej jest mówić w takim przypadku, za Leonem Petrażyckim, którego poglądy skądinąd wysoko cenił ${ }^{19}$, o ,prawie intuicyjnym” niż ,prawie natury”.

Gdy mowa o filozofii prawa, uznaje się, że pierwszy tego zwrotu użył Gustaw von Hugo w końcu XVIII w., a upowszechnił, za sprawą swojego ważnego dzieła Zasady filozofii prawa, Hegel ${ }^{20}$. Prawnicza refleksja, prowadzona w ramach szkoły historycznej (G. von Hugo był jej współtwórcą), zapoczątkowała spór metodologiczny dotyczący „wartości nauki prawa jako takiej”21. W centrum uwagi znalazło się pytanie, czy nowa dziedzina jurysprudencji, fi-

${ }^{14}$ Idem, Filozfja prawa we Francji, „Gazeta Sądowa Warszawska” 1910, nr 29-32, s. 452, 469.

${ }^{15}$ Ibidem, s. 453.

${ }^{16}$ Por. ibidem, s. 484.

${ }^{17}$ Ibidem, s. 469.

${ }^{18}$ Ibidem, przyp. 1 na s. 469.

${ }^{19}$ Gwoli ścisłości: Peretiatkowicz nie był zwolennikiem teorii Petrażyckiego w całości, ale aprobował jego metodę badań filozoficznych, empiryczno-indukcyjną, a nie, jak dawniej, racjonalistyczno-dedukcyjną (idem, Jellinek jako filozof prawa, „Gazeta Sądowa Warszawska” 1911, nr 14-19, przyp. 1 na s. 222).

${ }^{20}$ H. Izdebski, Elementy teorii i filozofii prawa, Warszawa 2008, s. 32.

${ }^{21}$ J. Stelmach, R. Sarkowicz, Filozofia prawa XIX i XX wieku, Kraków 1998, s. 20. 
lozofia prawa, może zasadnie nosić miano naukowej, czy jest tylko wyrazem subiektywnych poglądów osób nią się zajmujących. Jako że określenie jej statusu metodologicznego szczególnie zajmowało uwagę Peretiatkowicza ${ }^{22}$, kwestia ta zostanie niżej przybliżona.

Swoje stanowisko $\mathrm{w}$ tej kwestii formułuje, m.in. polemizując $\mathrm{z}$ argumentami zwolenników komparatystyki prawniczej, której pojawienie się było wynikiem ogólnego rozczarowania prawniczymi teoriami wieku XIX. Komparatystyka miała oparta być na indukcji i przez to wolna od indywidualnych upodobań myślicieli, co pozwoliłoby na wykrycie głównych linii rozwoju prawa i czynników nań wpływających ${ }^{23}$. Peretiatkowicz odnosi się krytycznie do tego stanowiska. Zauważa, że przed przystąpieniem do badań porównawczych należy mieć jakiekolwiek pojęcie o tym, czego się szukać będzie, trzeba ustalić zakres poszukiwań i dokonać analizy logicznej pojęcia prawa, w przeciwnym bowiem wypadku popadnięcie w błędne koło jest nieuniknio$\mathrm{ne}^{24}$. Polski naukowiec nie odrzuca jednak całkowicie metody komparatystycznej w badaniach nad prawem ${ }^{25}$. Widzi jej miejsce jako wsparcie dla nowoczesnej filozofii prawa. Ta ostatnia ma być ogólnym poglądem na prawo, tak jak filozofia ogólna stanowi ogólny pogląd na świat ${ }^{26}$. Niepodobna, zdaniem Peretiatkowicza, nie oprzeć filozofii prawa na podstawie empirycznej, czyli na wynikach doświadczenia, które dostarczyć mogą badania porównawcze; w filozofii prawa rozumianej jako nauka chodzić ma m.in. o umiejętną analizę zjawisk i wykrycie w nich cech wspólnych ${ }^{27}$. Aby filozofia prawa stała się pełnoprawną dziedziną nauki, musi się zwrócić w kierunku obiektywizmu i krytycyzmu, charakterystycznego ogólnie dla filozofii drugiej połowy XIX stulecia ${ }^{28}$. Nowa dziedzina nauki ma ,różnić się od innych gałęzi wiedzy (teoretycznej) jedynie przedmiotem i celem swoich badań, ale nie stosowaną metodą (w ogólnem znaczeniu)"29. Według Peretiatkowicza, filozofia prawa „szuka właściwej istoty prawa, niezależnie od sankcji państwowej, szuka samej idei prawnej, która winna leżeć u podstawy norm państwowych"30. W za-

${ }^{22}$ Warto ponadto nadmienić, że Peretiatkowicz zajmował się również historią filozofii prawa (A. Mycielski, Rozmowa z prof. dr hab. Andrzejem Mycielskim o filozofii prawa w okresie międzywojennym (rozmawiała M. Szyszkowska), „Ruch Filozoficzny” 1973, nr 2-4, s. 109).

${ }^{23}$ A. Peretiatkowicz, Filozofja prawa a metoda porównawcza, „Gazeta Sądowa Warszawska” 1908, nr 27-29, s. 437-438, 440.

${ }^{24}$ Ibidem, s. 464.

${ }^{25}$ Sam Peretiatkowicz prowadzi w pewnym zakresie badania porównawcze. Przykładem jest jego praca poświęcona wznowionej w 1908 r. konstytucji tureckiej z 1876 r. Por. idem, Konstytucja turecka na tle porównawczem, Warszawa 1908.

${ }^{26}$ Idem, Filozofja prawa a metoda porównawcza, op. cit., s. 463.

${ }^{27}$ Ibidem, s. 464.

${ }^{28}$ Idem, Jellinek..., s. 238.

${ }^{29}$ Ibidem.

${ }^{30}$ Idem, Wstęp do nauk prawnych, Poznań 1946, s. 27. Podobnie definiował filozofię prawa Eugeniusz Jarra, pisząc, że ma ona „za zadanie: całkować nauki prawne za pomocą wyprowadzania 
patrywaniu tym daje o sobie ponownie znać waga, jaką polski autor przykłada do potrzeby ustalenia w filozoficznej refleksji nad prawem apriorycznej idei prawa. Peretiatkowicz nie pomija wszak przy tym znaczenia i roli czynnika empirycznego, co wskazuje na rys umiarkowania i wyważenia w sądach formułowanych przez Profesora.

Poglądy polskiego badacza w tej materii są wypadkową dwóch ogólnych tendencji: z jednej strony, głębokiego przywiązania do wizji nauki jako sfery wolnej od subiektywizmu i jakiejkolwiek metafizyki, ale z drugiej, niechęci do zamknięcia się w ciasnych granicach materializmu i ścisłego empiryzmu. W tym kontekście należy zwrócić uwagę na przypadający w owym czasie filozoficzny ruch neokantowski nawołujący do powrotu do filozofii Immanuela Kanta, zwłaszcza że bezpośrednio oddziałuje on na kształtowanie stanowiska naukowego polskiego autora. Filozofia neokantowska była próbą przezwyciężenia wyżej wskazanego impasu między pragnieniem obiektywizacji wiedzy a jednoczesną niechęcią ku empiryzmowi, słowem, była protestem przeciwko obydwu skrajnościom ${ }^{31}$. Peretiatkowicz, będąc pod silnym wpływem neokantyzmu, o czym szerzej będzie mowa niżej, przenosi zasady tego nurtu filozoficznego na grunt metodologii nauk prawnych, czego logicznym i zrozumiałym wynikiem jego wizja filozofii prawa ${ }^{32}$ łącząca w kantowskim duchu racjonalizm z empiryzmem.

Nie można wszak przy tym zapominać, że w poglądach polskiego uczonego, oprócz dominującego wpływu neokantyzmu, daje się dostrzec również oddziaływanie filozofii pozytywistycznej, zwłaszcza analitycznej, będącej wówczas w Polsce, z uwagi na pozycję szkoły lwowsko-warszawskiej, najbardziej rozpowszechnioną. Dążenie do oparcia filozofii prawa na stricte naukowym gruncie, w ścisłej łączności z wynikami doświadczenia, jest modelowym wręcz przykładem tego. Przede wszystkim o łączności z tym nurtem filozoficznym decyduje, wyżej wskazane, co do istoty pozytywistyczne mimo znaczących koncesji na rzecz teorii prawnonaturalnych i modernizmu prawniczego, stanowisko Peretiatkowicza względem podstawowego źródła prawa, którym jest przede wszystkim ustawa. Ponadto, sam styl pracy Peretiatkowicza, tudzież stosowana metoda badań zdradza pozytywistyczną atmosferę epoki. W całej swojej działalności naukowej Peretiatkowicz będzie zawsze dążył do obiektywnego rozpatrzenia danego tematu, starając się wnikliwie i bezstronnie przedstawić każdy jego aspekt, przy czym w swoich polemikach i analizach krytycznych wypowiadać się będzie z neutralnej perspektywy naukowej.

jedności ich najogólniejszych zasad; wyjaśniać te ostatnie, względnie krytykować z punktu widzenia pewnych postulatów prawa idealnego" (E. Jarra, Ogólna teorja prawa, Warszawa 1922, s. 9).

${ }^{31}$ Por. M. Szyszkowska, Neokantyzm. Filozofia spoleczna wraz z filozofia prawa natury o zmiennej treści, Warszawa 1970, s. 15.

${ }^{32}$ Podobnie filozofię prawa rozumieli również neokantyści Emil Lask oraz Leonard Nelson (por. T. Gadacz, Historia filozofii XX wieku. Nurty, t. 2, Kraków 2009, s. 303, 358-359). 
Aby uczynić kompletnym obraz filozoficznych inspiracji polskiego uczonego, warto wspomnieć jeszcze o znaczeniu fenomenologii, jednego z nurtów filozoficznych zapoczątkowanego w drugiej połowie wieku XIX przez Edmunda Husserla. Jego uczeń Adolf Reinach zastosował fenomenologiczne podejście, aczkolwiek modyfikując zasady Husserla, do badań nad prawem, które miały polegać na poszukiwaniu istoty pojęć prawnych, takich jak umowa czy własność ${ }^{33}$. Reinach uważał, że w instytucjach prawnych, nawet mimo ich pochodzenia od pozytywnego ustawodawcy, daje się odkryć pewne aprioryczne jądro, bez którego dany przedmiot nie mógłby w ogóle istnieć. Dla przykładu, umowa, aby była umową, musi zawierać w sobie pewien zespół cech konstytutywnych, które ustanawiają jej byt niezależnie od tego, w jakim systemie normatywnym to pojęcie funkcjonuje. Reinach wprost stwierdzał, że „prawo pozytywne zastaje (vorfinden) pojęcia prawne, które wchodzą w jego skład; bynajmniej ich nie tworzy"34. Co więcej, aprioryczne prawa odnaleźć można także w obszarach nieobjętych regulacją pozytywnoprawną ${ }^{35}$. Można sądzić, że Peretiatkowicz, który często w swoich analizach filozoficzno-prawnych rozpatruje dane zagadnienie z punktu widzenia istoty samego prawa, który wpierw stara się ją określić podając jej elementy pierwotne, w pewien sposób wpisuje się również po części w fenomenologiczny nurt. Nie można tutaj wszak mówić o inspiracjach bezpośrednich, ich śladów nie odnaleziono bowiem w materiale zgromadzonym na potrzeby niniejszej pracy, ale można stwierdzić, że pewien sposób myślenia o prawie, kształtowany również pod wpływem dokonań Reinacha, wpływa na zajmujących się wówczas refleksją filozoficzno-prawną uczonych, wśród których znajduje się także Antoni Peretiatkowicz, przesiąkający, być może automatycznie i bezrefleksyjnie, panującym wówczas klimatem intelektualnym epoki.

4. W dziedzinie filozofii prawa polski badacz nie ograniczał się tylko do sprecyzowania wymagań stawianej nowej nauce i śledzenia jej historii. W sporze między szkołą prawa natury a pozytywizmem, postrzegając obydwa te nurty jako jednostronne, Peretiatkowicz zajmuje stanowisko pośrednie. Stwierdza, że idea prawa naturalnego nie ma ,wiecznej i niezmiennej treści, lecz zależy od warunków miejsca i czasu, od całokształtu kultury (religijnej, moralnej i socjalnej) danego społeczeństwa", i jako wyraz ideałów prawnych powinna stanowić punkt odniesienia przy tworzeniu i interpretacji prawa pozytywnego ${ }^{36}$. Formułuje również własną teorię prawa natury opartą na pojęciu poczucia prawnego ${ }^{37}$.

${ }^{33}$ M. Zirk-Sadowski, Wprowadzenie do filozofii prawa, Zakamycze 2000, s. 61.

${ }^{34}$ A. Reinach, Aprioryczne podstawy prawa cywilnego, przeł. T. Bekrycht, Kraków 2009, s. 42.

${ }^{35}$ Ibidem, s. 45.

${ }^{36}$ A. Peretiatkowicz, Wstęp..., s. 28-29.

${ }^{37}$ Opis teorii prawa natury Peretiatkowicza opracowano w niniejszej pracy na podstawie: A. Kryniecka-Piotrak, Koncepcja poczucia prawnego w ujęciu Antoniego Peretiatkowicza, [w:] 
Uważał, że jedynym dopuszczalnym, z naukowego punktu widzenia, sposobem ujmowania prawa natury jest jego sprowadzenie do zbioru przeżyć psychicznych jednostki. Wyróżnia dwa rodzaje poczucia prawnego: społeczne i indywidualne. Pierwsze z nich obejmuje złożony zespół wierzeń, obyczajów, poglądów, czy stylu myślenia wspólnych dla danego społeczeństwa. Poczucie indywidualne, z kolei, jest właściwym pojedynczej jednostce nastawieniem psychicznym, odróżniającym to, co legalne od tego, co z prawem niezgodne. Kształtowane jest przez szereg czynników społecznych, wychowawczych, jak też wrodzonych. Jest szersze przedmiotowo, gdyż oprócz indywidualnego światopoglądu obejmuje poczucie społeczne właściwe dla zbiorowości, w której dana jednostka żyje. Peretiatkowicz uważa, że źródłem przestrzegania prawa, posłuchu dla jego norm, nie jest w pierwszej kolejności znajomość treści konkretnego systemu prawnego, lecz właśnie poczucie prawne, w procesie socjalizacji wpajane jednostce. Na co dzień ta ostatnia odkrywa niejako intuicyjnie zachowania dopuszczalne w danym układzie stosunków. Określając prawo natury, polski autor upatruje go we właściwym dla danego czasu, miejsca i środowiska poczuciu społecznym, implikującym wzorce należytego zachowania, jak również postulaty zmian stanu dotychczasowego. Jak nietrudno zauważyć, koncepcja Peretiatkowicza jest teorią eklektyczną; widać w niej wyraźny wpływ popularnych wówczas poglądów Rudolfa Stammlera i Leona Petrażyckiego. Stanowi razem z nimi przykład teorii prawa natury o zmiennej treści. Maria Szyszkowska określa je mianem teorii gnoseologicznych, upatrujących źródła prawa natury nie w istocie człowieka, lecz uznających je za wytwór jego rozumu i stworzonej przez niego kultury.

Przywołanie nazwiska Stammlera i wpływu jego teorii na Peretiatkowicza skłania do skrótowego przedstawienia, zgodnie z wytyczonym na wstępie porządkiem, fenomenu filozofii neokantowskiej, której Stammler, obok Radbrucha, był najważniejszym przedstawicielem na gruncie filozofii prawa.

W połowie XIX w. dochodzi w Niemczech do większego poruszenia akademickiego i ciekawości okazywanej Immanuelowi Kantowi, wzrostu znaczenia badań poświęconych jego filozofii i metodzie. Coraz częściej dają się słyszeć głosy ważnych postaci ówczesnego świata intelektualnego bezpośrednio nawołujące do ponownego odkrycia myśli filozofa z Królewca. Pierwszy hasło rzucił Otto Liebmann w swojej książce, w której każdy wywód krytyczny miał w zwyczaju kończyć słowami: ,a więc należy powrócić do Kanta”38. Przedstawiciele nowego nurtu, zwanego neokantyzmem lub neokrytycyzmem, nie pragnęli wszak wiernie recypować przemyśleń autora trzech Krytyk, lecz interesowali się głównie stosowaną przez niego metodą, chciano „filozofować w oparciu o Kanta, ale nie implikowało to jeszcze wiernopoddańczej deklara-

M. Szyszkowska, Teoria i filozofia prawa, Warszawa 2008, s. 216-222; M. Szyszkowska, Teorie..., s. 127-130; eadem, Zarys..., s. 224-225.

${ }^{38}$ W. Tatarkiewicz, Historia filozofii, t. 3, Warszawa 2007, s. 105. 
cji w stosunku do mistrza" ${ }^{39}$. Zwracano się głównie w kierunku kantowskiej krytyki poznania, której nie uwzględniała ani heglowska metafizyka, ani materializm przyrodników. Rozczarowanie tymi dwoma ostatnimi stanowiskami filozoficznymi było właśnie przyczyną powstania nowej szkoły, której przedstawiciele zaznaczyli się również na gruncie filozofii prawa. Odnośnie do poglądów Peretiatkowicza nietrudno zauważyć, choćby tylko na przykładzie jego wizji filozofii prawa czy autorskiej koncepcji prawa natury, że pozwalają one uznać polskiego autora za reprezentanta szkoły neokantowskiej w Polsce, a bardziej ogólnie za jednego z kontynuatorów zapoczątkowanego przez Kanta nurtu filozoficznego ${ }^{40}$.

Omawiając wpływ filozofii neokantowskiej na stanowisko naukowe Peretiatkowicza, warto jeszcze krótko nadmienić o stosunku polskiego uczonego względem - wywodzącej się również z kręgów neokantowskich, aczkolwiek w swoich wnioskach radykalnie odmiennej od poglądów formułowanych w ramach teorii prawa natury o zmiennej treści - koncepcji normatywizmu autorstwa Hansa Kelsena. Jak wyżej zauważono, Peretiatkowicz co do zasady jest zwolennikiem pozytywizmu prawnego, lecz jednocześnie, dostrzegając problemy, z którymi nie jest w stanie uporać się ta doktryna w jej ortodoksyjnym ujęciu, optuje za włączeniem w pozytywistyczny paradygmat istotnych elementów o zabarwieniu prawnonaturalnym czy socjologicznoprawnym. $\mathrm{Z}$ tego względu ustalenia Kelsena, zgodnie z którymi wszelkie prawo zamyka się i ogranicza do sformalizowanego i zamkniętego systemu norm prawa pozytywnego, nie są dla Peretiatkowicza możliwymi do przyjęcia.

W wyniku studiów nad myślą Kelsena Peretiatkowicz ${ }^{41}$, wszak zgadzając się, jak przystało na kantystę, z rozdzieleniem świata bytu i powinności, krytykuje jednak twierdzenie Austriaka o identyczności państwa i prawa, ponieważ, jak stwierdza Peretiatkowicz, ,system norm, opartych na normie podstawowej, nosi charakter w znacznej mierze subiektywny, a państwo nosi charakter obiektywny. Istnienie państwa nie zależy od uznania jednostki, która - według teorii Kelsena - wybiera normę podstawową, a więc decyduje o systemie norm"42. Ponadto, działalność państwa nie polega tylko na tworzeniu prawa, lecz również wykracza poza działania przewidziane przez normy prawne. Peretiatkowicz nie zgadza się także z Kelsenowską tezą, jakoby państwo można badać jedynie z prawnego punktu widzenia, gdyż nie ma przeszkód, aby w tym wymiarze prowadzić również badania socjologiczne.

${ }^{39}$ M. Szyszkowska, Neokantyzm..., s. 14.

${ }^{40}$ Szerzej o kantowskich inspiracjach Peretiatkowicza por. K. Kuźmicz, Immanuel Kant jako inspirator polskiej teorii i filozofii prawa w latach 1918-1950, Białystok 2009, s. 157-175.

${ }^{41}$ Por. A. Peretiatkowicz, O istocie metody prawniczej (teoria H. Kelsena), Warszawa 1937, s. 89-92. Szerzej: idem, Teoria prawa i państwa H. Kelsena, [w:] idem, Studia prawnicze, op. cit., s. $3-79$.

${ }^{42}$ Idem, $O$ istocie metody..., s. 90. 
Uważa, iż nie do utrzymania jest, poza tym, Kelsenowski prymat prawa międzynarodowego nad prawem wewnętrznym, który, zdaniem polskiego uczonego, jest przejawem myślenia pacyfistycznego niż prawa obowiązującego. Mimo to traktuje teorię Kelsena jako istotnej rangi dokonanie intelektualne, wskazując wszak, że ,zasadniczym błędem Kelsena jest zupełne wyeliminowanie momentów teleologicznych. Zapoznaje on, że nauki prawne należą do nauk praktycznych, przy których chodzi nie tylko o prawdę logiczną, ale także o spełnienie pewnej funkcji społecznej"43. Jak łatwo zauważyć, w stwierdzeniu tym daje znać o sobie właściwa Peretiatkowiczowi wrażliwość na uwzględnienie w kontekście studiów nad prawem perspektywy socjologicznej, co również należy potraktować jako jedną z cech charakterystycznych jego filozofii prawa.

Krótko podsumowując, można stwierdzić, że filozoficzno-prawna myśl Peretiatkowicza nosi znamiona jawnie neokantowskiej proweniencji, lecz jednocześnie daje się w myśli tej odnaleźć wyraźny wpływ poglądów właściwych szkole socjologicznej w jurysprudencji oraz Leonowi Petrażyckiemu. Odnaleźć w niej także można nawiązania do doktryny pozytywizmu prawniczego, lecz potraktowanej krytycznie i istotnie zmodyfikowanej. Nie można przy tym zapominać, że koncepcje polskiego autora nie tylko wpisują się w filozofię prawa, lecz z uwagi na czas, w którym powstały, także przyczyniły się do powstania filozofii prawa jako odrębnej dyscypliny naukowej.

5. Jak wiadomo, klimat intelektualny drugiej połowy XIX stulecia ulegał znacznym przeobrażeniom. Na polu filozofii ogólnej oraz prawoznawstwa zostały zakwestionowane dominujące wcześniej nurty myślowe. Załamuje się scjentystyczny paradygmat naukowy, wzrok dużej części ludzi nauki odwraca się od ściśle materialistycznego i empirycznego ujmowania zjawisk filozoficznych. Nieuchronnie prowadzi to do głębokiego zainteresowania twórczością myślicieli wieków wcześniejszych. Hasła Rewolucji Francuskiej oraz związane z nią prądy ideowe wzbudzają ponownie szeroki odzew w środowiskach akademickich. Teorie prawa natury, poglądy filozofów XVII i XVIII w., jak choćby Hobbesa, Pufendorfa czy Locke'a, a przede wszystkim Jana Jakuba Rousseau, stają się przedmiotem szerokich badań ${ }^{44}$. Nie chodzi, oczywiście, o proste przeniesienie tych koncepcji na czasy schyłku XIX w., ale o krytyczne ich opracowanie, o powtórny namysł nad oświeceniowymi ideami. Co najistotniejsze, przestaje się je postrzegać jako przedmioty wyłącznie badań historycznych, ale zaczyna się je traktować jako źródło cennych i użytecznych wskazówek przy rozwiązywaniu istotnych problemów bieżącego życia politycznego, społecznego oraz prawnego.

\footnotetext{
${ }^{43}$ Ibidem, s. 92.

${ }^{44}$ S. Bukowiecki, Filozofia prawa J.J. Rousseau, „Przegląd Filozoficzny” 1898-99, z. 2, s. 65-66.
} 
Zainteresowanie postacią i filozofią Rousseau w Polsce spowodowane jest zapewne również związkiem tego myśliciela z polską historią. W końcu był on autorem, napisanych na prośbę konfederaty barskiego hr. Wielhorskiego, Uwag o rzadzie polskim, dzieła zawierającego projekt przebudowy i reformy ustrojowej upadającej I Rzeczypospolitej. Idee szwajcarskiego pisarza wpłynęły na program „stronnictwa republikańskiego” oraz dają się dostrzec w pismach Kołłątaja, a przede wszystkim Staszica ${ }^{45}$. Polemizował natomiast z Janem Jakubem, w związku z ukazaniem się jego głośnej Rozprawy o naukach i sztukach, wówczas już były król polski Stanisław Leszczyński ${ }^{46}$. Biorąc pod uwagę wszystkie powyższe czynniki, nie mogą dziwić słowa z początku XX w., że „Zwrot ku Rousseau’owi może być najbardziej rozświetlającym momentem odrodzenia umysłowości zbiorowej" ${ }^{47}$.

Jako że w takim otoczeniu intelektualnym swoją pracę badawczą rozpoczynał Antoni Peretiatkowicz, nie może zaskakiwać fakt, że w polu jego zainteresowań naukowych znalazła się myśl Jana Jakuba. Antoni Peretiatkowicz zaczyna prowadzić swoje badania nad twórczością Jana Jakuba na początku XX stulecia, przetłumaczy na język polski Umowę społeczną i doktrynie Rousseau poświęci swoje dzieło największe, które doczekało się trzech wydań $^{48}$, i które do dnia dzisiejszego stanowi jedno z głównych opracowań w polskiej bibliografii russologicznej. Jako jeden z pierwszych w Polsce Peretiatkowicz zajął się przybliżeniem oraz krytycznym i kompleksowym opracowaniem politycznej myśli Jana Jakuba, stając się czołowym w Polsce znawcą poglądów Rousseau. Buduje własną interpretację teorii genewskiego myśliciela, odnosząc się często do istniejących wówczas głównie niemieckich i francuskich komentarzy oraz analiz w tym zakresie. Zawarte w monografii wnikliwe uwagi i oryginalne wnioski stawiają tę pracę na najwyższym światowym poziomie. Choćby tylko pobieżny przegląd analiz Peretiatkowicza nad

${ }^{4}$ W.M. Kozłowski, Rousseau i Polska (dodatek), [w:] H. Hettner, J.J. Rousseau, przeł. M. Pieńkowska, Warszawa 1914, s. 108-110.

${ }^{46}$ Por. Odpowiedź króla polskiego na rozprawę Jana Jakuba Rousseau, [w:] J.J. Rousseau, Trzy rozprawy z filozofii społecznej, przeł. H. Elzenberg, Warszawa 1956, s. 47-65.

${ }^{47}$ W.M. Kozłowski, Rousseau i Polska (dodatek), op. cit., s. 123.

${ }^{48}$ Wyd. I: A. Peretiatkowicz, Filozofia prawa Jana Jakóba Rousseau'a, Kraków 1913; wyd. II: idem, Filozofia społeczna J.J. Rousseau'a, Poznań 1921; wyd. III: idem, Jan Jakub Rousseau. Filozof demokracji społecznej, Poznań 1949. Wydanie drugie, w treści swej niezmienione, różni się jedynie tytułem, który ma bardziej odpowiadać charakterowi twórczości Rousseau (z Przedmowy do drugiego wydania) oraz zawiera krótki dodatek o życiu i dziełach Rousseau. W wydaniu trzecim, które ukazało się już po II wojnie światowej, w nowych warunkach politycznych i ustrojowych, ostatni dotychczasowy rozdział poświęcony filozofii karnej Rousseau zastąpiony został rozważaniami dotyczącymi idei demokracji społecznej. Niektóre rozdziały monografii ukazały się z nieznacznymi zmianami również jako osobne artykuły czy studia: idem, Filozofia natury Jana Jakóba Rousseau'a, „Biblioteka Warszawska” 1912, t. IV, z. 1, s. 56-99; idem, Idea umowy społecznej w rozwoju historycznym, Poznań 1920; idem, Umowa spoleczna Jan Jakóba Rousseau'a na tle historycznem, „Themis Polska” 1913, t. I, poszyt 2. 
myślą Rousseau przekracza ramy niniejszej pracy, wskazać w tym miejscu jedynie można, że w dziele Peretiatkowicza dogłębnym studiom poddane zostały najważniejsze dla filozofii politycznej Rousseau zagadnienia natury, prawa naturalnego, umowy społecznej i ,woli powszechnej”. W pierwszych dwóch wydaniach dzieła uwaga zwrócona została ponadto na, rzadko poruszaną w studiach nad myślą Rousseau, filozofię karną szwajcarskiego myśliciela. W rozważaniach Peretiatkowicza wskazane zostało m.in. wątpliwe, gdy przyjmie się założenia umowy społecznej, uzasadnienie wykonywania kary śmierci (jednostki przypuszczalnie nie zgodziłyby się na pozbawienie życia), prewencyjny, a nie tylko odwetowy charakter kary, oraz wpływ Jana Jakuba na Cesare Beccarię.

Oryginalność i ponadczasowość wartości pracy wynika również z obranej przez jej autora metodologii. Peretiatkowicz bowiem czytał Rousseau nie jako historyk, lecz jego rozważania miały charakter, jak sam to określił, filozoficzno-prawny, w ograniczonym zakresie nawiązujący do faktów historycznych i analiz porównawczych. Metoda ta „musi dane historyczne uwzględniać, jako środek dla poznania i wyświetlania samej doktryny, ale wybiega poza te dane faktyczne, analizując treść myślową, niezależnie od rzeczywistej (znanej lub hipotetycznej) świadomości odnośnego myśliciela"49. Peretiatkowicz traktuje przemyślenia Rousseau jako aktualne i wartościowe dla współczesnej myśli politycznej i prawnej. Podkreśla znaczenie idei umowy społecznej dla nowoczesnych społeczeństw ${ }^{50}$ i tym samym wpisuje się w szerszy prąd powrotu haseł Oświecenia, przełamujący XIX-wieczny paradygmat prawny i polityczny. Twierdzi, że z punktu widzenia społecznie-indywidualistycznego konstrukcja „umowy społecznej” ma istotne znaczenie metodologiczne $\mathrm{i}$,zasługuje na większą uwagę, niż to miało miejsce w okresie pozytywizmu prawniczego, w drugiej połowie XIX stulecia" ${ }^{51}$. Jak zauważył Jerzy Lande, książka Peretiatkowicza, poświęcona twórczości genewskiego myśliciela, włącza się w odrodzenie prawa naturalnego i zwrot od ciasnego pozytywi$\mathrm{zmu}^{52}$. Opus magnum Peretiatkowicza w całości wpisuje się w jego zapatrywania filozoficzno-prawne i stanowi przykład konsekwentnego budowania jednolitego stanowiska naukowego. Monografia o Rousseau oddaje ówczesny klimat intelektualny, krytyczny w dużej mierze względem dominujących w wieku XIX prądów myślowych, jest też przykładem potrzeby poszukiwania nowej podbudowy ideowej dla teoretycznego ujmowania państwa, prawa czy społeczeństwa, do czego Antoni Peretiatkowicz nie tylko swoim dziełem o Rousseau, lecz całą swoją twórczością, w znacznym stopniu się przyczynił.

${ }^{49}$ Idem, Jan Jakub Rousseau..., s. 10-11.

${ }^{50}$ M. Szyszkowska, Zarys..., s. 225.

${ }^{51}$ A. Peretiatkowicz, Filozofia spoleczna..., s. 209.

52 J. Lande, recenzja wydania I (Filozofia prawa Jana Jakóba Rousseau'a), „Themis Polska” 1914 , t. IV, poszyt 1 i 2 , s. 285-286. 
Rekapitulując, wypada stwierdzić, że przełom XIX i XX w. przynosi szereg istotnych zmian $\mathrm{w}$ myśleniu o prawie. Zauważa się odejście od dominujących wcześniej nurtów historycznego i pozytywistycznego, połączone z powrotem do idei prawa natury, przy czym ta ostatnia ujawnia się głównie pod postacią Stammlerowskiej koncepcji prawa natury o zmiennej treści oraz Petrażyckiego teorii ,prawa intuicyjnego”. W związku z tymi przemianami konstytuuje się nowa dyscyplina naukowa - filozofia prawa. Ówczesny nurt prawnonaturalny ściśle wiąże się z powstaniem szkół neokantowskich w Niemczech i powrotem myśli Kanta. Rousseau, jako jeden z głównych inspiratorów królewieckiego filozofa, jest również postacią wzbudzającą zainteresowania, czego dowodzi szereg opracowań jemu poświęconych. Antoni Peretiatkowicz, bacznie śledząc te wydarzenia i mając kontakt z czołowymi przedstawicielami nauki owego czasu, był uczonym, który swoim dorobkiem naukowym wniósł istotny wkład w rozwój tych idei, idei, które, jak wiadomo, wykroczyły poza swoją epokę i wpłynęły na kształt dzisiejszego świata. Choćby tylko z tego powodu warto traktować prace Peretiatkowicza jako aktualne i mające znaczenie także obecnie. 
